\title{
Structural quality indicators in compacted oxisols grown with corn
}

\author{
Karina de Vares Rossetti ${ }^{1}$, José Frederico Centurion ${ }^{2}$ \\ ${ }^{1}$ Universidade do Estado de Mato Grosso, Campus Pontes e Lacerda, Pontes e Lacerda, Mato Grosso, Brasil. E-mail: \\ krossetti@bol.com.br \\ ${ }^{2}$ Universidade Estadual Paulista, Campus Jaboticabal, Jaboticabal, São Paulo, Brasil. E-mail: jfcentur@fcav.unesp.br
}

Received: 30/05/2020; Accepted: 28/07/2020.

\section{ABSTRACT}

In the face of the elevated cost of economic and environmental order to recover degraded soil, the monitoring of the structural quality of the soil through physical and plant indicators is recommended. This way, this work aimed to verify which parameters may be used together with soil penetration resistance (PR), after compression induced by agricultural machinery traffic in Haplustox (LVd) and an Eutrustox (LVef), grown with corn. The experiment was conducted with a randomized block design in a split-plot scheme with four replications. Five treatments and three soil layers $(0-0.10 ; 0.10-0.20$, and $0.20-0.30 \mathrm{~m})$ for each soil class were evaluated. The treatments were: $\mathrm{NC}=$ conventional preparation without additional compression; $\mathrm{C} 14, \mathrm{C} 17$, and $\mathrm{C} 110=$ one pass of a tractor of 4,7 , and $10 \mathrm{Mg}$, respectively; $\mathrm{C} 310=$ three passes of the tractor of $10 \mathrm{Mg}$. The variables evaluated were aggregate stability index, soil density (Ds), soil porosity, PR, and root and height variables, diameter, and kernel yield of the corn crop. PR increased with higher compression in the LVd, and in C14, C17, C110, and C310 in the layer of 0.10-0.30 $\mathrm{m}$ in LVef. Ds and root area of the corn are useful to analyze the structural quality of the soil together with the PR.

Keywords: Root growth, Agricultural machinery, Soil attributes.

\section{Indicadores da qualidade estrutural em latossolos compactados cultivados com milho}

\section{RESUMO}

Diante do elevado custo de ordem econômica e ambiental para recuperar um solo degradado, recomenda-se o monitoramento da qualidade estrutural do solo por meio de indicadores físicos e da planta. Dessa forma, objetivouse com este trabalho verificar quais parâmetros podem ser utilizados juntos com a resistência do solo à penetração (RP), após a compactação induzida por tráfego de máquinas agrícolas em um Latossolo Vermelho Distrófico (LVd) e em um Latossolo Vermelho Eutroférrico (LVef), cultivados com milho. O experimento foi conduzido em delineamento de blocos casualizados em parcelas subdivididas, com cinco tratamentos, três camadas $(0-0,10 ; 0,10$ 0,20 e 0,20-0,30 m) e quatro repetições, para cada classe de solo. Os tratamentos foram: $\mathrm{SC}=$ preparo convencional sem compactação adicional; $\mathrm{C} 14, \mathrm{C} 17$ e C110= uma passada do trator de 4, 7 e $10 \mathrm{Mg}$, respectivamente; $\mathrm{C} 310=$ três passadas do trator de $10 \mathrm{Mg}$. As variáveis avaliadas foram: estabilidade de agregados, densidade (Ds), porosidade do solo, RP e variáveis da raiz e da altura, diâmetro e produtividade da cultura do milho. A RP aumentou com o incremento da compressão ao solo no LVd e no C14, C17, C110 e C310 na camada de 0,10-0,30 $\mathrm{m}$ no LVef. A Ds e a área radicular do milho são úteis para analisar a qualidade estrutural do solo em conjunto com a RP.

Palavras-chave: Crescimento radicular, Máquina agrícola, Atributos do solo. 


\section{Introduction}

The harmful alterations to soil structure and the growth of plants may occur due to the inappropriate use of agricultural machinery associated with the increase of the operational capacity of the machines, inadequate intensity of the traffic, besides poor administration of waste and reposition of organic matter.

According to the Food and Agriculture Organization (FAO, 2015), approximately 33\% of soils around the world are degraded. An example of such a factor is soil compaction, which threatens its quality and agricultural production. For this reason, the identification of the compressive behavior of the soil is essential and useful for the prevention and evaluation of its compaction (Imhoff et al., 2016; Keller et al., 2013).

This way, penetration resistance (PR) has been applied regularly as an attribute to evaluate the intensity of soil compaction (Bengough et al., 2011), for presenting direct relations with the porous system of the soil (Valentine et al., 2012), with the development of crops and roots (Bergamin et al., 2010b). Also, it is more efficient in the identification of the states of compaction compared to soil bulk density (Silva et al., 2003).

The PR value of $2 \mathrm{MPa}$, generally considered critical, may not be appropriate for any tillage system. However, this value was accepted by decades as restrictive for root growth in most crops (Otto et al., 2011). In this sense, this PR value should be maintained for the conventional preparation system (Moraes et al., 2014). Results obtained by Barbosa et al. (2018) indicate variation in the PR depending on the soil, on its texture, and state that the clayey soil has a higher critical limit than in sandy loam soil.

Since the inappropriate cultivation of soil alters the physical attributes regarding the non-cultivated soil, the need to quantify and qualify the structural conditions of the soil appears. In this aspect, since there is an expenditure of human and financial resources to obtain soil parameters and/or of the plant, nothing is more viable than to previously knowing which parameters that possess the higher degree of dependence among themselves are.

Therefore, this study aimed to verify which parameters may be used, in addition to the PR, to evaluate the structural quality of the soil, after compression induced by the traffic of agricultural machinery in Haplustox (LVd) and an Eutrustox (LVef) grown with corn. The choice of Oxisols was due to the higher occurrence in Brazil (approximately 30\%) (Resende et al., 2019) and in the region where the experiment was carried out.

\section{Material and Methods}

The study was carried out in Jaboticabal, SP, at coordinates: $21^{\circ} 14^{\prime} 05^{\prime \prime} \mathrm{S}, 48^{\circ} 17^{\prime} 09^{\prime \prime} \mathrm{W}$, with an altitude of $615 \mathrm{~m}$. The weather of the region, according to the weather classification of Köppen, is Cwa type, with hot summer and dry winter, annual mean rainfall of $1.428 \mathrm{~mm}$, and mean temperature of $21^{\circ} \mathrm{C}$.

The soils were classified according to Embrapa (2018) as Haplustox (Latossolo Vermelho Distrófico), typical, mean texture, A moderate, (kaolinitichypoferric LVd), which the material of origin was derived mainly from the sandstones in the Bauru Group in the flattest and elevated portions; and Eutrustox (Latossolo Vermelho Eutroférrico), typical, clayey texture, A moderate, kaolinitic-oxidic (LVef), originated mainly from the products of basalt alterations (General Mountain Formation), subjacent to the sandstones. The soils presented, in the $0-0.20 \mathrm{~m}$ layer, 348 and $560 \mathrm{~g} \mathrm{~kg}^{-}$ ${ }^{1}$ of clay, 598 and $240 \mathrm{~g} \mathrm{~kg}^{-1}$ of sand, 54 and $200 \mathrm{~g} \mathrm{~kg}^{-1}$ of silt, and 2.89 and $2.74 \mathrm{Mg} \mathrm{m}^{-3}$ of particle density (Embrapa, 2017), respectively in the LVd and LVef. Before the equipment installation, the conventional preparation of the soil $0.30 \mathrm{~m}$ deep was performed, followed by a leveling harrowing.

The experiment was conducted with a randomized block design in a split-plot scheme with four replications. The random effects to the plots were: soil with conventional tillage and without additional tractor traffic (NC); one pass of the $4 \mathrm{Mg}$ tractor $(\mathrm{C} 14)$; one pass of the $7 \mathrm{Mg}$ tractor (C17); one (C110) and three (C310) passes of the $10 \mathrm{Mg}$ tractor. The soil compression was then performed through the passage of the tractor wheels in the whole surface of the plots in a way that the tires compressed parallel areas. The number of times that the tractors passed ranged according to the treatment. The traffic was overlaid to the previous one, in a way that the complete area of each plot had an equal number of times of passes. The treatments were constituted by plots and soil layers (0-0.10; 0.10-0.20 e 0.20-0.30 m) as sub-plots. An area of native forest (NF) was used as a control for the evaluation of the physical attributes of soil for the LVd and LVef.

The treatments were established in November 2012, when the soil presented an amount of water equivalent to the field capacity of 0.12 and $0.22 \mathrm{~kg} \mathrm{~kg}^{-1}$ for the $\mathrm{LVd}$ and LVef, respectively, on the 0-0.20 m layer (Embrapa, 2017). To establish the C14 treatment, a tractor with 56 $\mathrm{kW}$ (69.04 hp) was used, with inflation pressure in the R1 front tires of $83 \mathrm{kPa}$ and the rear tires (R1 18.4-30) of 96 $\mathrm{kPa}, 4 \times 2$ traction and weight of $4 \mathrm{Mg}$, with a distribution of $30 \%$ of the total mass on the front diagonal wheels and $70 \%$ on the rear radial wheels. 
The tractor used for the $\mathrm{C} 17$ treatment had $77 \mathrm{~kW}$ (103.56 hp), with auxiliary front-wheel drive (4 x 2) and a weight of $7 \mathrm{Mg}$, with a distribution of $40 \%$ of the total mass on the radial front wheels and $60 \%$ on the rear radial wheels. For the $\mathrm{C} 110$ and $\mathrm{C} 310$, a loading shovel

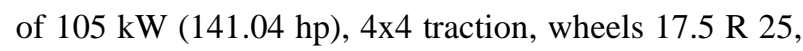
radial (L-3), a weight of $10 \mathrm{Mg}$ was used, with the bucket empty. The operations were performed at a speed of $\leq 5 \mathrm{~km} \mathrm{~h}^{-1}$, with tires calibrated and in good state of conservation.

The corn sowing (Maximus single-cross hybrid) was performed in December 2012, using a seed drill machine of direct sowing with five rows. The shank was removed so it would not eliminate the possible negative effects of the compression, being used only the cutting disk from the seed drill. The sowing density was to from five to six seeds per meter, with a row spacing of $0.90 \mathrm{~m}$. The experimental plots were constituted of five rows 6 $\mathrm{m}$ long, considering as the useful area the three central rows, discarding $1.5 \mathrm{~m}$ from each extremity, totaling 5.4 $\mathrm{m}^{2}$.

The chemical analysis of the soil (0-0.20 m layer) was performed according to Raij et al. (2001) (Table 1). The fertilization consisted of the application of $340 \mathrm{~kg}$ $\mathrm{ha}^{-1}$ of the NPK formulation, 8:28:16, to obtain the expected grain yield from 6 to $8 \mathrm{Mg} \mathrm{ha}^{-1}$. The topdressing fertilization was performed with $250 \mathrm{~kg} \mathrm{ha}^{-1}$ from the NPK formulation, 20:0:20, on the soil surface, close to the corn rows, with the same seed drill machine used for sowing. For the cultural treats, the same tractor used in treatment $\mathrm{C} 17$ was used, with the amount of water close to the field capacity.

For the determination of the soil physical attributes, undefined samples were collected between the corn rows, with cylinders of $53.1810^{-6} \mathrm{~m}^{3}(0.032 \mathrm{~m}$ high and $0.046 \mathrm{~m}$ diameter). The samples were saturated for $24 \mathrm{~h}$ and submitted to the chambers of Richards in -0.01 MPa. When they reach the equilibrium, they were weighed, and the soil penetration resistance (PR) was determined, in each intermediate layer of the cylinder, totaling 100 readings by sample to obtain the mean PR. PR was determined through a static electronic penetrometer, with a constant velocity of penetration of $1 \mathrm{~cm} \mathrm{~min}-1$, angle cone of $30^{\circ}$ and with a base area of $4.90910^{-6} \mathrm{~m}^{2}$, equipped with linear actuator and load cell of $20 \mathrm{~kg}$ attached to a microcomputer for data acquisition, as described by Tormena et al. (1998). Next, samples were dried in an incubator at $105^{\circ} \mathrm{C}$ for $24 \mathrm{~h}$, to determine the soil bulk density (Ds). Microporosity (mic) was determined by drying, and macroporosity (mac) was calculated as being the difference between total porosity and mic (Embrapa, 2017).

Also, samples were collected between the corn rows with the aid of a hoe, to obtain stability of aggregates in all evaluated layers of the experiment. Thus, samples to determine the amount of organic matter (OM) were also collected, according to the method described by Raij et al. (2001). Clods of soil were dried at room temperature and manually destroyed to evaluate the stability of aggregates by the humid way; $50 \mathrm{~g}$ of soil were used, sieved in a mesh of $7.93 \mathrm{~mm}$ and retained in a mesh of $4.0 \mathrm{~mm}$, which were pre-moistened, according to the Kemper and Chepil (1965). The samples were placed in the device of vertical oscillation over a set of sieves of $4.00 ; 2.00 ; 1.00 ; 0.50 ; 0.25$, and $0.125 \mathrm{~mm}$ diameter of mesh opening, according to described by Yoder (1936). Fifteen minutes passed, the portions in each mesh were removed to aluminum cans with the aid of water jets and dried in an oven at $105^{\circ} \mathrm{C}$, for $24 \mathrm{~h}$, for posterior weighing. From the values of those masses, the percentage of stable aggregates in water with a diameter bigger than $2.0 \mathrm{~mm}(\mathrm{Ag}>2)$, the mean geometric diameter (MGD), and mean weight diameter (MWD) were calculated, according to Kemper and Chepil (1965).

During the corn tasseling stage (VT), in March 2013, three samples per plot and layer were obtained. For this, a bucket auger was used, distanced by $0.2 \mathrm{~m}$ from the stem of corn plants. The images of the roots were scanned in an optical reading scanner, at $400 \mathrm{dpi}$ resolution, which provided the area (RA), the mean diameter of the root (RD), and root length (RL) by Delta-T Scan software. The density of root length (DRL) was determined by the division of the RL by the volume of the collected soil $\left(481.06 \mathrm{~cm}^{-3}\right)$. The samples were dried in an oven at $65^{\circ} \mathrm{C}$ until reaching constant mass, to determine the mass of root dry matter (RDM), which was divided by the volume of the collected soil, obtaining the root tissue density (RTD).

Table 1. Chemical characteristics of the Haplustox (LVd) and Eutrustox (LVef) in the $0-0.20 \mathrm{~m}$ layer, before implementing the experiment.

\begin{tabular}{ccccccccccc}
\hline Soil & $\begin{array}{c}\mathrm{pH} \\
\mathrm{CaCl}_{2}\end{array}$ & $\begin{array}{c}\mathrm{OM} \\
\mathrm{g} \mathrm{dm}^{-3}\end{array}$ & $\begin{array}{c}\text { P-resin } \\
\mathrm{mg} \mathrm{dm}^{3}\end{array}$ & $\begin{array}{c}\mathrm{K}^{+} \\
--------------------m m o l c ~ \mathrm{dm}^{-3}---\mathrm{Ca}^{2+}\end{array}$ & $\mathrm{Mg}^{2+}$ & $\mathrm{H}+\mathrm{Al}$ & $\mathrm{CEC}$ & $\begin{array}{c}\mathrm{V} \\
\%\end{array}$ \\
\hline LVd & 5.6 & 14 & 40 & 2.0 & 21 & 17 & 20 & 40 & 60 & 67 \\
MNLVd & 6.0 & 16 & 45 & 3.5 & 39 & 22 & 10 & 64 & 74 & 86 \\
LVef & 4.9 & 24 & 61 & 2.7 & 30 & 12 & 27 & 45 & 72 & 62 \\
MNLVef & 5.8 & 31 & 55 & 3.3 & 42 & 30 & 15 & 75 & 90 & 83 \\
\hline
\end{tabular}

OM: organic matter; SB: sum of bases; CEC: cations exchange capacity; V: base saturation; NF: native forest; ${ }^{(1)}$ cultivate: area submitted to the conventional tillage and soil compression. 
In the stage R6 of corn, the plant height was determined, though the distance between the soil surface and the tassel insertion. Also, the stem diameter was determined by the average between two readings in the second internode of the stem, with a digital pachymeter. Ten plants per plot were evaluated. The grain yield was obtained by extrapolating the production of grains in the useful area of the plot to 1 ha, adjusting the humidity of the grains to $13 \%$.

Data were submitted to the Shapiro Wilk and Levene tests, both with $\mathrm{p}<0.05$, to verify the normality of the residues and homoscedasticity of the variances, respectively. Only the root variations of the study did not present normal distribution and homoscedasticity, having, therefore, the need to transform the data in $\sqrt{x+0.5}$. The results obtained were then submitted to variance analysis through the software Assistat version 7.7 beta, and when significant, the means were compared by the Tukey test $(\mathrm{p}<0.05)$. To verify which soil and plant parameters may be used together with PR to evaluate the structural quality of the soil, multiple regression was employed using the software Statistica version 7.0 .

\section{Results and Discussion}

The stability of the aggregates (Table 2), verified through the mean geometric diameter, mean weight diameter, and from $\mathrm{Ag}>2$ in $\mathrm{LVd}$ showed similar behavior among all the treatments $\mathrm{NC}, \mathrm{C} 14, \mathrm{C} 17, \mathrm{C} 110$, and $\mathrm{C} 310$ when compared in the layers $0-0.10 \mathrm{~m}$ and $0.20-0.30 \mathrm{~m}$. It was observed in this case that the signal of structural degradation in $\mathrm{LVd}$ occurred in the same intensity for all treatments in these layers. Due to the physical attributes of LVd being inferior to the values quantified in the NF, the most significant difference in the values was observed in the $0-0.10 \mathrm{~m}$ layer. It is worth mentioning that only in the $0.10-0.20 \mathrm{~m}$ layer in LVd that C14 was superior compared to the other treatments.

Table 2. Percentage of water-stable aggregates $>2 \mathrm{~mm}(\mathrm{Ag}>2)$, mean geometric diameter (MGD), and mean weight diameter (MWD) in Oxisols under different treatments, in different layers.

\begin{tabular}{|c|c|c|c|c|c|c|}
\hline \multirow[t]{4}{*}{ Treatments } & \multicolumn{3}{|c|}{ LVV_ } & \multicolumn{3}{|c|}{ LVef } \\
\hline & MGD & MWD & $\mathrm{Ag}>2$ & MGD & MWD & $\mathrm{Ag}>2$ \\
\hline & \multicolumn{2}{|c|}{-----------mm----------- } & $\%$ & \multicolumn{2}{|c|}{-----------mm---------- } & $\%$ \\
\hline & \multicolumn{6}{|c|}{$0-0.10 \mathrm{~m}$} \\
\hline $\mathrm{NC}$ & $0.62 \mathrm{Aa}$ & $1.07 \mathrm{Aa}$ & $13.84 \mathrm{Aa}$ & $1.36 \mathrm{Aa}$ & $2.40 \mathrm{Aa}$ & $41.00 \mathrm{Aa}$ \\
\hline $\mathrm{C} 14$ & $0.79 \mathrm{Ab}$ & $1.50 \mathrm{Ab}$ & $22.90 \mathrm{Aa}$ & $1.55 \mathrm{Aa}$ & $2.58 \mathrm{Aa}$ & $44.58 \mathrm{Ab}$ \\
\hline $\mathrm{C} 17$ & $0.64 \mathrm{Aa}$ & $1.20 \mathrm{Aa}$ & $16.72 \mathrm{Aa}$ & $1.51 \mathrm{Aa}$ & $2.46 \mathrm{Ab}$ & $43.33 \mathrm{Ab}$ \\
\hline $\mathrm{C} 110$ & $0.73 \mathrm{Aa}$ & $1.30 \mathrm{Aa}$ & $17.91 \mathrm{Aa}$ & $2.33 \mathrm{Aa}$ & $3.37 \mathrm{Aa}$ & $58.21 \mathrm{Aa}$ \\
\hline $\mathrm{C} 310$ & $0.73 \mathrm{Aa}$ & $1.38 \mathrm{Aa}$ & $19.71 \mathrm{Aa}$ & $1.70 \mathrm{Aa}$ & $2.66 \mathrm{Aa}$ & $47.13 \mathrm{Aa}$ \\
\hline Mean & 0.70 & 1.29 & 18.22 & 1.69 & 2.69 & 46.85 \\
\hline \multirow[t]{2}{*}{$\mathrm{NF}$} & 5.57 & 5.73 & 99.04 & 5.67 & 5.78 & 99.35 \\
\hline & \multicolumn{6}{|c|}{$0.10-0.20 \mathrm{~m}$} \\
\hline $\mathrm{NC}$ & $0.63 \mathrm{BCa}$ & $1.12 \mathrm{Ba}$ & $14.77 \mathrm{Ba}$ & $1.40 \mathrm{Aa}$ & $2.42 \mathrm{Aa}$ & $42.57 \mathrm{Aa}$ \\
\hline $\mathrm{C} 14$ & $0.96 \mathrm{Aa}$ & $1.88 \mathrm{Aa}$ & $29.16 \mathrm{Aa}$ & $2.12 \mathrm{Aa}$ & $3.30 \mathrm{Aa}$ & $59.14 \mathrm{Aa}$ \\
\hline $\mathrm{C} 17$ & $0.64 \mathrm{Ba}$ & $1.04 \mathrm{BCa}$ & $12.50 \mathrm{BCa}$ & $1.75 \mathrm{Aa}$ & $2.79 \mathrm{Aab}$ & 49.63 Aab \\
\hline $\mathrm{C} 110$ & $0.49 \mathrm{BCb}$ & $0.70 \mathrm{BCb}$ & $5.28 \mathrm{Cb}$ & $1.87 \mathrm{Aab}$ & $2.86 \mathrm{Aab}$ & $50.83 \mathrm{Aab}$ \\
\hline $\mathrm{C} 310$ & $0.45 \mathrm{Cc}$ & $0.62 \mathrm{Cb}$ & $3.89 \mathrm{Cb}$ & $1.46 \mathrm{Aa}$ & $2.32 \mathrm{Aa}$ & $40.64 \mathrm{Aa}$ \\
\hline Mean & 0.63 & 1.07 & 13.12 & 1.72 & 2.74 & 48.56 \\
\hline \multirow[t]{2}{*}{$\mathrm{NF}$} & 5.50 & 5.74 & 97.62 & 5.72 & 5.83 & 99.22 \\
\hline & \multicolumn{6}{|c|}{$0.20-0.30 \mathrm{~m}$} \\
\hline $\mathrm{NC}$ & $0.67 \mathrm{Aa}$ & $1.06 \mathrm{Aa}$ & $12.16 \mathrm{Aa}$ & $1.83 \mathrm{Aa}$ & $2.93 \mathrm{Aa}$ & $51.12 \mathrm{Aa}$ \\
\hline $\mathrm{C} 14$ & $0.61 \mathrm{Ac}$ & $1.03 \mathrm{Ac}$ & $13.50 \mathrm{Ab}$ & $1.92 \mathrm{Aa}$ & $2.59 \mathrm{Aa}$ & $50.61 \mathrm{Aab}$ \\
\hline $\mathrm{C} 17$ & $0.59 \mathrm{Aa}$ & $0.91 \mathrm{Aa}$ & $9.97 \mathrm{Aa}$ & $2.12 \mathrm{Aa}$ & $3.26 \mathrm{Aa}$ & $57.74 \mathrm{Aa}$ \\
\hline $\mathrm{C} 110$ & $0.59 \mathrm{Ab}$ & $0.85 \mathrm{Ab}$ & $8.13 \mathrm{Ab}$ & $1.36 \mathrm{Ab}$ & $2.25 \mathrm{Ab}$ & $39.47 \mathrm{Ab}$ \\
\hline C310 & $0.60 \mathrm{Ab}$ & $0.90 \mathrm{Ab}$ & $9.28 \mathrm{Ab}$ & $1.51 \mathrm{Aa}$ & $2.43 \mathrm{Aa}$ & $42.46 \mathrm{Aa}$ \\
\hline Mean & 0.61 & 0.95 & 10.61 & 1.75 & 2.69 & 48.28 \\
\hline NF & 2.57 & 3.87 & 66.53 & 5.31 & 5.58 & 97.13 \\
\hline $\mathrm{F}^{1}$ & $6.23^{* *}$ & $7.83^{* * *}$ & $9.12^{* *}$ & $0.64^{\mathrm{ns}}$ & $0.51^{\mathrm{ns}}$ & $0.58^{\mathrm{ns}}$ \\
\hline $\mathrm{F}^{2}$ & $8.01^{* * *}$ & $15.84^{* * *}$ & $17.78^{* *}$ & $0.13^{\mathrm{ns}}$ & $0.08^{\mathrm{ns}}$ & $0.25^{\mathrm{ns}}$ \\
\hline$F^{1 \times 2}$ & $9.40^{* *}$ & $8.02^{* * *}$ & $6.44^{* *}$ & $3.90^{* * *}$ & $3.81^{* * *}$ & $3.41^{* * *}$ \\
\hline $\mathrm{CV}(\%)^{1}$ & 16.95 & 23.75 & 37.73 & 41.51 & 33.89 & 33.39 \\
\hline $\mathrm{CV}(\%)^{2}$ & 11.63 & 17.49 & 29.40 & 20.68 & 15.97 & 17.19 \\
\hline
\end{tabular}

NC: without compaction, C14, C17, and C110: one pass of a tractor of 4, 7, and $10 \mathrm{Mg}$, respectively, C310: three passes of a tractor of $10 \mathrm{Mg}$. NF: native forest in Haplustox (LVd) and Eutrustox (LVef). (1) $\mathrm{CV}$ (plots) ${ }^{(2)} \mathrm{CV}$ (subplots). Mean followed by the same letter do not differ by the Tukey test $(\mathrm{p}<0.05)$; capital letters refer to the comparison of treatments in the lines; lowercase letters refer to the comparison of layers in the same treatment, in the columns. ns $=$ not significant and ${ }^{* *}$ significant $(\mathrm{p}<0.01)$. 
When MGD, MWD, and $\mathrm{Ag}>2$ are analyzed in LVef, it cannot be affirmed which treatment presented the smaller value in the evaluated layers, showing similar conditions to LVd, however, in all layers. Since $\mathrm{LVd}$ in this study was characterized as hypoferric $(54 \mathrm{~g}$ $\mathrm{kg}^{-1}$ of $\mathrm{Fe}_{2} \mathrm{O}_{3}$ ), it was already expected smaller stability of aggregates, in this case, comparing to the management cultivated in LVef $\left(205 \mathrm{~g} \mathrm{~kg}^{-1}\right.$ of $\left.\mathrm{Fe}_{2} \mathrm{O}_{3}\right)$.

Therefore, the level of disaggregation in the treatments submitted to compaction induced by tractors was the same as the NC. Thus, in this study, the formation of "false aggregates" did not occur, which means, it did not have the effect of "mechanical aggregation" due to the tension executed by the compaction that would result in the union of particles under high content of water in the soil. According to Nunes et al. (2015), the rupture of aggregates after the soil's scarification results in an enhance of microaggregates and a reduction in the stability of aggregates. Typically, the NC conducts to the destruction of macroaggregates, increasing the number of microaggregates in the soil. In this aspect, according to Nascente et al. (2015), the treatment of fallow under $\mathrm{NC}$ in LVd exhibited a higher number of aggregates smaller than $2 \mathrm{~mm}$, followed by a smaller number of aggregates bigger than $8 \mathrm{~mm}$ in the $0-0.20 \mathrm{~m}$ layer. For this reason, the results presented in this study make it clear the need to be cautious when choosing the type of equipment and regarding the intensity of traffic of agricultural machinery during crop management in the area.

In both soils, it can be noticed higher values of $\mathrm{Ag}>$ 2, MGD, and MWD in NF corroborating with the study of Rossetti et al. (2013) in LVd. These authors verified that the soil management provided a reduction of the index of aggregation. Therefore, it could prove the loss of stability of aggregates due to the agricultural use, regarding NF. Despite the less dependence of OM in the stability of microaggregates in tropical soil, this attribute has also influenced in the aggregation of NF. This pattern is due to the higher contribution of plant material in the NF, providing enhance in the level of $\mathrm{OM}$ and, consequently, aggregation increment in the soil. A similar situation was proven by Balin et al. (2017), which affirm that from the $0.10-0.20 \mathrm{~m}$ layer in a Red Oxisol, the area of NF presented higher MGD regarding areas with anthropic activity. According to the authors above, this fact highlights the greater state of organization of the soil under the natural system, even in the condition of less organic carbon and total.

The traffic of machinery altered the Ds with higher intensity on the superficial layers $(0.10-0.20 \mathrm{~m}$ and 0.20-0.30 m) (Table 3). An increase of the compaction occurred in $\mathrm{C} 14, \mathrm{C} 110$, and $\mathrm{C} 310$ in $\mathrm{LVd}$, and in $\mathrm{NC}$, $\mathrm{C} 14, \mathrm{C} 17$, and C110 in LVef when compared to the 0$0.10 \mathrm{~m}$ layer. This way, the previous usage of a disc harrow after scarification may be favored the formation of physical hindrances just below the soil layers monitored by the implements. It was observed that the sub-superficial layer continued to suffer compaction with the enhancement of the traffic of tractors. The difference of values in both soils is due to the smaller value of density of the particle in both LVef $(2.74 \mathrm{Mg}$ $\left.\mathrm{m}^{-3}\right)$ and $\mathrm{LVd}\left(2.89 \mathrm{Mg} \mathrm{m}^{-3}\right)$.

These results corroborate the ones by Reichert et al. (2009) who verified, after analyzing a database from the literature, that the critical bulk density of the soil decreases with the enhance of the clay content. In this aspect, in both soils, the values of Ds in NF were inferior in all the layers when compared to all the cultivated treatments. Due to the high values of OM in NF (Table 1), the susceptibility to the compaction in the environment without anthropic action becomes smaller regarding managed areas. Since the damping effect of the OM results in the dissipation of part of the applied energy. Another complement to this justification is that in the area of natural vegetation, there is probably bigger vegetal diversity, which implies a wider variety of other living organisms in the soil, which contribute to the development of a more porous structure and less dense in the soil.

In this aspect, Bergamin et al. (2010a) obtained higher Ds values, in the $0-0.10 \mathrm{~m}$ layer, in Rhodic Acrustox with clayey texture, starting from two passes of a tractor with $5 \mathrm{Mg}$ in the no-tillage system regarding when compared to the treatment without additional compaction. According to these authors, four or six passes with the tractor did not enhance the Ds when compared to two passes.

In LVef, the change in Ds due to the traffic of machinery resulted in a decrease of mac around 34.5\% in the $\mathrm{C} 310$ when compared to the $\mathrm{NC}$ in the $0-0.10 \mathrm{~m}$ layer. In the layers of $0.10-0.20$ and $0.20-0.30 \mathrm{~m}$, it was observed that the mac in LVef was not altered in depth between the treatments, and it was regardless of the number of passes and mass of the tractors.

The behavior in the LVef corroborates the observation pointed out by Freddi et al. (2009), in which the traffic of tractors modifies the mac only on the superficial layer $(0-0.20 \mathrm{~m})$. Values of mac lower than $0.10 \mathrm{~m}^{3} \mathrm{~m}^{-3}$ in the LVef were found in the $0.20-0.30 \mathrm{~m}$ layer in C14 $\left(0.084 \mathrm{~m}^{3} \mathrm{~m}^{-3}\right)$, in the $0.10-0.30 \mathrm{~m}$ layer (0.098 and $\left.0.089 \mathrm{~m}^{3} \mathrm{~m}^{-3}\right)$ in $\mathrm{C} 110$, and in all the studied layers $\left(0.067 ; 0.091\right.$, and $\left.0.082 \mathrm{~m}^{3} \mathrm{~m}^{-3}\right)$ in $\mathrm{C} 310$. These results may indicate a probable limitation to soil aeration even in the moister season. 
Table 3. Density, macroporosity, and microporosity of the Haplustox (LVd) and the Eutrustox (LVef), under different intensities of traffic and native forest, in different layers.

\begin{tabular}{|c|c|c|c|c|c|c|c|}
\hline \multirow{2}{*}{ Layer (m) } & \multicolumn{7}{|c|}{ Treatments } \\
\hline & $\mathrm{NC}$ & $\mathrm{C} 14$ & C17 & $\mathrm{C} 110$ & C310 & Mean & $\mathrm{NF}$ \\
\hline \multicolumn{8}{|c|}{ Soil Bulk Density $\left(\mathrm{Mg} \mathrm{m}^{-3}\right)$} \\
\hline \multicolumn{8}{|c|}{ LVd } \\
\hline $0-0.10$ & $1.58 \mathrm{Aa}$ & $1.37 \mathrm{Bb}$ & $1.44 \mathrm{ABa}$ & $1.59 \mathrm{Ab}$ & $1.58 \mathrm{Ab}$ & 1.51 & 1.21 \\
\hline $0.10-0.20$ & $1.65 \mathrm{BCa}$ & $1.66 \mathrm{BCa}$ & $1.52 \mathrm{Ca}$ & $1.73 \mathrm{ABa}$ & $1.84 \mathrm{Aa}$ & 1.68 & 1.38 \\
\hline $0.20-0.30$ & $1.55 \mathrm{Ca}$ & $1.62 \mathrm{BCa}$ & $1.55 \mathrm{Ca}$ & $1.78 \mathrm{ABa}$ & $1.85 \mathrm{Aa}$ & 1.67 & 1.44 \\
\hline \multirow[t]{3}{*}{ Mean } & 1.59 & 1.55 & 1.50 & 1.70 & 1.76 & & \\
\hline & $\mathrm{F}^{1}=11.63^{* *}$ & & $\mathrm{~F}^{2}=32.46^{* *}$ & & $\mathrm{~F}^{1 \mathrm{X} 2}=3.54^{* *}$ & & \\
\hline & \multicolumn{2}{|c|}{$\mathrm{CV}(\%)^{1}=6.58$} & & \multicolumn{4}{|c|}{$\mathrm{CV}(\%)^{2}=4.54$} \\
\hline \multicolumn{8}{|c|}{ LVef } \\
\hline $0-0.10$ & $135 \mathrm{Bb}$ & $1.30 \mathrm{Bb}$ & $1.24 \mathrm{Bb}$ & $1.21 \mathrm{Bb}$ & $1.69 \mathrm{Aa}$ & 1.36 & 0.98 \\
\hline $0.10-0.20$ & $1.47 \mathrm{BCa}$ & $1.51 \mathrm{Ba}$ & $1.36 \mathrm{Ca}$ & $1.51 \mathrm{Ba}$ & $1.66 \mathrm{Aa}$ & 1.50 & 1.05 \\
\hline $0.20-0.30$ & $1.37 \mathrm{Cab}$ & $1.47 \mathrm{BCa}$ & $1.34 \mathrm{Ca}$ & $1.58 \mathrm{ABa}$ & $1.64 \mathrm{Aa}$ & 1.48 & 1.14 \\
\hline Mean & 1.40 & 1.43 & 1.31 & 1.43 & 1.66 & & \\
\hline & $\mathrm{F}^{1}=27.80^{* *}$ & & $\mathrm{~F}^{2}=37.32^{* *}$ & & $\mathrm{~F}^{1 \mathrm{X} 2}=9.09^{* * *}$ & & \\
\hline \multicolumn{4}{|c|}{$\mathrm{CV}(\%)^{1}=5.92$} & \multicolumn{4}{|c|}{$\mathrm{CV}(\%)^{2}=3.92$} \\
\hline \multicolumn{8}{|c|}{ Macroporosity $\left(\mathrm{m}^{3} \mathrm{~m}^{-3}\right)$} \\
\hline \multicolumn{8}{|c|}{$\mathrm{LVd}$} \\
\hline $0-0.10$ & 0.154 & 0.205 & 0.216 & 0.137 & 0.128 & $0.168 a$ & 0.292 \\
\hline $0.10-0.20$ & 0.161 & 0.148 & 0.167 & 0.104 & 0.076 & $0.131 b$ & 0.188 \\
\hline $0.20-0.30$ & 0.153 & 0.080 & 0.146 & 0.076 & 0.077 & $0.106 c$ & 0.181 \\
\hline \multirow[t]{3}{*}{ Mean } & $0.156 A$ & $0.144 A$ & $0.176 A$ & $0.106 B$ & $0.093 B$ & & 0.220 \\
\hline & $\mathrm{F}^{1}=19.47^{* *}$ & & $\mathrm{~F}^{2}=19.78^{* *}$ & & $\mathrm{~F}^{1 \mathrm{X} 2}=2.24^{\mathrm{ns}}$ & & \\
\hline & \multicolumn{2}{|c|}{$\mathrm{CV}(\%)^{1}=20.28$} & & \multicolumn{4}{|c|}{$\mathrm{CV}(\%)^{2}=23.24$} \\
\hline \multicolumn{8}{|c|}{ LVef } \\
\hline $0-0.10$ & $0.194 \mathrm{Aa}$ & $0.132 \mathrm{Aa}$ & $0.139 \mathrm{Aa}$ & $0.188 \mathrm{Aa}$ & $0.067 \mathrm{Ba}$ & 0.144 & 0.338 \\
\hline $0.10-0.20$ & $0.136 \mathrm{Ab}$ & $0.115 \mathrm{Aa}$ & $0.103 \mathrm{Aa}$ & $0.098 \mathrm{Ab}$ & $0.091 \mathrm{Aa}$ & 0.109 & 0.300 \\
\hline $0.20-0.30$ & $0.131 \mathrm{Ab}$ & $0.084 \mathrm{Aa}$ & $0.129 \mathrm{Aa}$ & $0.089 \mathrm{Ab}$ & $0.082 \mathrm{Aa}$ & 0.103 & 0.299 \\
\hline Mean & 0.154 & 0.110 & 0.124 & 0.125 & 0.080 & & \\
\hline & $\mathrm{F}^{1}=6.55^{* *}$ & & $\mathrm{~F}^{2}=12.32^{* *}$ & & $\mathrm{~F}^{1 \mathrm{X} 2}=3.61^{* *}$ & & \\
\hline \multicolumn{4}{|c|}{$\mathrm{CV}(\%)^{1}=30.41$} & \multicolumn{4}{|c|}{$\mathrm{CV}(\%)^{2}=23.84$} \\
\hline \multicolumn{8}{|c|}{ Microporosity $\left(\mathrm{m}^{3} \mathrm{~m}^{-3}\right)$} \\
\hline \multicolumn{8}{|c|}{$\mathrm{LVd}$} \\
\hline $0-0.10$ & 0.215 & 0.212 & 0.218 & 0.215 & 0.225 & $0.217 b$ & 0.240 \\
\hline $0.10-0.20$ & 0.226 & 0.233 & 0.221 & 0.221 & 0.240 & $0.228 a$ & 0.215 \\
\hline $0.20-0.30$ & 0.218 & 0.220 & 0.218 & 0.226 & 0.215 & $0.219 a b$ & 0.229 \\
\hline \multirow[t]{3}{*}{ Mean } & $0.220^{n s}$ & $0.222^{n s}$ & $0.219^{n s}$ & $0.221^{n s}$ & $0.227^{n s}$ & & 0.228 \\
\hline & $\mathrm{F}^{1}=0.62^{\mathrm{ns}}$ & & $\mathrm{F}^{2}=3.93^{*}$ & & $\mathrm{~F}^{1 \mathrm{X} 2}=0.98^{\mathrm{ns}}$ & & \\
\hline & \multicolumn{2}{|c|}{$\mathrm{CV}(\%)^{1}=6.17$} & & & $\mathrm{CV}(\%)^{2}$ & & \\
\hline & & & $\mathrm{LVe}$ & & & & \\
\hline $0-0.10$ & 0.339 & 0.348 & 0.348 & 0.345 & 0.338 & $0.343^{n s}$ & 0.334 \\
\hline $0.10-0.20$ & 0.366 & 0.345 & 0.363 & 0.373 & 0.376 & $0.365^{n s}$ & 0.330 \\
\hline $0.20-0.30$ & 0.343 & 0.407 & 0.350 & 0.398 & 0.380 & $0.376^{n s}$ & 0.353 \\
\hline Mean & $0.349^{n s}$ & $0.367^{n s}$ & $0.354^{n s}$ & $0.372^{n s}$ & $0.365^{n s}$ & & 0.339 \\
\hline & $\mathrm{F}^{1}=0.64^{\mathrm{ns}}$ & & $\mathrm{F}^{2}=2.87^{\mathrm{ns}}$ & & $\mathrm{F}^{1 \mathrm{X} 2}=0.74^{\mathrm{ns}}$ & & \\
\hline & $\mathrm{CV}(\%$ & 1.12 & & & $\mathrm{CV}(\%)^{2}=$ & & \\
\hline
\end{tabular}

NC: without compaction, C14, C17, and C110: one pass of a tractor of 4, 7, and $10 \mathrm{Mg}$, respectively, C310: three passes of a tractor of $10 \mathrm{Mg}$. NF: native forest in Haplustox (LVd) and Eutrustox (LVef). ${ }^{(1)} \mathrm{CV}$ (plots) ${ }^{(2)} \mathrm{CV}$ (subplots). Mean followed by the same letter do not differ by the Tukey test $(\mathrm{p}<0.05)$; capital letters refer to the comparison of treatments in the lines; lowercase letters refer to the comparison of layers in the same treatment, in the columns. ns = not significant; ${ }^{*}$ significant $(\mathrm{p}<0.05)$, and ${ }^{* *}$ significant $(\mathrm{p}<0.01)$.

When the difference in mean values of mac is observed in NF and managed areas (Table 3), it is possible to state that there are higher values in $\mathrm{NF}$ in the layers of $0-0.10 \mathrm{~m} ; 0.10-0.20 \mathrm{~m}$, and $0.20-0.30 \mathrm{~m}$ in LVd $\left(0.124 ; 0.057\right.$, and $0.075 \mathrm{~m}^{3} \mathrm{~m}^{-3}$, respectively, and $\mathrm{OM}=30 \mathrm{~g} \mathrm{dm}^{-3}$ (Table 1), and in LVef $(0.194 ; 0.191$, and $0.196 \mathrm{~m}^{3} \mathrm{~m}^{-3}$, respectively, and $\mathrm{OM}=55 \mathrm{~g} \mathrm{dm}^{-3}$ (Table 1). Since the values of OM in LVd for NF are not close to the treatments submitted to the soil management, probably the reduction of mac within these treatments is also a result of the actions of compaction induced by the tractors to the soil.

The treatments $\mathrm{C} 110$ and $\mathrm{C} 310$ in $\mathrm{LVd}$ had the smaller values of mac when compared to the other treatments, being observed the decrease in the subsurface (Table 3). In both soils, it was verified that 
the mic was not sensitive to the modifications caused by the traffic of tractors, and nor in the NC. This behavior can be justified due to the strong influence of mic to the texture and content of OM; however, there is low interference of the increase in Ds caused by the machinery traffic.

PR increased with the increment of soil compaction induced by the traffic of tractors in $\mathrm{LVd}$ and the treatments of $\mathrm{C} 14, \mathrm{C} 17, \mathrm{C} 110$, and $\mathrm{C} 310$ in the 0.10 $0.30 \mathrm{~m}$ layer in LVef (Table 4). This way, these results agree with the ones obtained by Bergamin et al. (2010a), working with Rhodic Acrustox and the traffic of a machine with $5 \mathrm{Mg}$. According to Oliveira et al. (2012), PR also suffered an increase with the traffic of the $11 \mathrm{Mg}$ tractor when compared to the condition with no traffic in the $0-0.10 \mathrm{~m}$ layer in LVef. In LVd, the compressions $\mathrm{C} 14$ and $\mathrm{C} 17$ did not differ regarding PR in the layers of $0-0.10 \mathrm{~m}, 0.10-0.20 \mathrm{~m}$, and $0.20-0.30 \mathrm{~m}$, and a similar situation was found for the LVef in the layers of $0.10-0.20 \mathrm{~m}$ and $0.20-0.30 \mathrm{~m}$.

In $\mathrm{C} 110(0-0.30 \mathrm{~m})$ and $\mathrm{C} 310(0-0.20 \mathrm{~m})$ in $\mathrm{LVd}$ and in NC (0.20-0.30 m), C14 (0-0.10 m), C110 (0-0.30 m) and C310 (0-0.20 m) in LVef, the PR was $2 \mathrm{MPa}$. Such value, usually used as critical, cannot be accepted as appropriate to all systems of preparation, although this value has been accepted for decades as restrictive for root growth in most cultures (Otto et al., 2011).

According to Freddi et al. (2007), from the PR value of 1.65 MPa in $\mathrm{LVd}$, corn yield started to decrease. In contrast, PR values in NF did not reach levels of inhibition of root development and were lower than the mean of treatments. This way, the results from the present study followed the ones presented by Teixeira et al. (2017) in an NF area in the Cerrado in comparison to the values lower than $2 \mathrm{MPa}$ in areas under grazing and no-tillage system. According to Freitas et al. (2010), this is due to the accumulation of plant residue on the soil's surface associated with its high humidity, which contributes to the increase in the OM content in NF, as shown in Table 1.

All the variables of the corn's root system RA (root area), RD (root diameter), RL (root length), DRL (density of the root length), RDM (root dry matter), and RTD (root tissue density) in both LVd and LVef did not suffer the effect of compressions (Table 5).

Except for RD in both soils, the rest of the root's variables presented the statistical difference between the layers. Thus, this contradicts the results of RD obtained by Freddi et al. (2009) in LVd in the 0-0.30 m layer according to the level of compression employed. The usage of compression presented less negative effect for the $0-0.10 \mathrm{~m}$ layer, due to higher values of RA, RL, DRL, and RTD in LVd, and of RA, RL, and DRL in LVef.

In both soils, even with the increase of the Ds and PR associated with the reduction of mac in the treatments under compression, root growth was not harmed. This behavior, although contradictory, has also been proven by Freddi et al. (2007) in the $0-0.10 \mathrm{~m}$ layer. Despite high PR in C310 (2.66 MPa) in the 0.10$0.20 \mathrm{~m}$ layer in $\mathrm{LVd}$ and the same treatment (3.46 MPa) in the $0.20-0.30 \mathrm{~m}$ layer in the LVef regarding the other treatments with additional compressions, this fact did not interfere in any root variable.

Table 4. Effect of the compaction on the soil penetration resistance in LVd and LVef cultivated with corn and native forest.

\begin{tabular}{|c|c|c|c|c|}
\hline \multirow[b]{2}{*}{ Treatments } & \multicolumn{4}{|c|}{ Soil Penetration Resistance (MPa) } \\
\hline & $0-0.10 \mathrm{~m}$ & $0.10-0.20 \mathrm{~m}$ & $0.20-0.30 \mathrm{~m}$ & Mean \\
\hline $\mathrm{NC}$ & $1.11 \mathrm{Ba}$ & $1.12 \mathrm{Ca}$ & $1.25 \mathrm{Ba}$ & 1.16 \\
\hline $\mathrm{C} 14$ & $0.54 \mathrm{Cb}$ & $1.34 \mathrm{Ca}$ & $1.31 \mathrm{Ba}$ & 1.06 \\
\hline $\mathrm{C} 17$ & $0.65 \mathrm{Cb}$ & $1.40 \mathrm{Ca}$ & $1.15 \mathrm{Ba}$ & 1.07 \\
\hline C110 & $2.83 \mathrm{Aa}$ & $2.11 \mathrm{Bb}$ & $2.71 \mathrm{Aa}$ & 2.55 \\
\hline C310 & $2.84 \mathrm{Aab}$ & $2.66 \mathrm{Ab}$ & $3.10 \mathrm{Aa}$ & 2.87 \\
\hline Mean & 1.59 & 1.73 & 1.90 & \\
\hline \multirow[t]{3}{*}{ NF } & 0.33 & 0.91 & 1.10 & \\
\hline & $\mathrm{F}^{1}=327.44^{* *}$ & $\mathrm{~F}^{2}=10.63^{* *}$ & $\mathrm{~F}^{1 \mathrm{X} 2}=9.38^{* *}$ & \\
\hline & $\mathrm{CV}(\%)^{1}=9.79$ & & $\mathrm{CV}(\%)^{2}=12.34$ & \\
\hline \multicolumn{5}{|c|}{ LVef } \\
\hline Treatments & $0-0.10 \mathrm{~m}$ & $0.10-0.20 \mathrm{~m}$ & $0.20-0.30 \mathrm{~m}$ & Mean \\
\hline $\mathrm{NC}$ & $0.82 \mathrm{Cb}$ & $1.16 \mathrm{Db}$ & $2.48 \mathrm{Ba}$ & 1.49 \\
\hline C14 & $2.01 \mathrm{Ba}$ & $1.78 \mathrm{BCa}$ & $1.59 \mathrm{CDa}$ & 1.79 \\
\hline $\mathrm{C} 17$ & $1.07 \mathrm{Cb}$ & $1.56 \mathrm{CDa}$ & 1.26 Dab & 1.30 \\
\hline $\mathrm{C} 110$ & $2.30 \mathrm{ABa}$ & $2.15 \mathrm{ABa}$ & $2.07 \mathrm{BCa}$ & 2.17 \\
\hline C310 & $2.70 \mathrm{Ab}$ & $2.46 \mathrm{Ab}$ & $3.46 \mathrm{Aa}$ & 2.87 \\
\hline Mean & 1.78 & 1.82 & 2.17 & \\
\hline \multirow[t]{3}{*}{$\mathrm{NF}$} & 0.43 & 0.54 & 0.67 & \\
\hline & $\mathrm{F}^{1}=56.87^{* *}$ & $\mathrm{~F}^{2}=13.63^{* *}$ & $\mathrm{~F}^{1 \mathrm{X} 2}=13.71^{* *}$ & \\
\hline & $\mathrm{CV}(\%)^{1}=14.90$ & & $\mathrm{CV}(\%)^{2}=13.52$ & \\
\hline
\end{tabular}

NC: without compaction, C14, C17, and C110: one pass of a tractor of 4, 7, and $10 \mathrm{Mg}$, respectively, C310: three passes of a tractor of $10 \mathrm{Mg}$. NF: native forest in Haplustox (LVd) and Eutrustox (LVef). (1) CV (plots) ${ }^{(2)} \mathrm{CV}$ (subplots). Mean followed by the same letter do not differ by the Tukey test $(\mathrm{p}<0.05)$; capital letters refer to the comparison of treatments in the lines; lowercase letters refer to the comparison of layers in the same treatment, in the columns. $n s=$ not significant and ${ }^{* *}$ significant $(\mathrm{p}<0.01)$. 
Table 5. Root area (RA), root diameter (RD), root length (RL), density of the root length (DRL), root dry matter (RDM), and root tissue density (RTD) of corn cultivated in two different soils, LVd and LVef, under different compressions.

\begin{tabular}{|c|c|c|c|c|c|c|}
\hline Compression & $\begin{array}{c}\mathrm{RA} \\
\mathrm{mm}^{2}\end{array}$ & $\begin{array}{l}\mathrm{RD} \\
\mathrm{mm}\end{array}$ & $\begin{array}{l}\mathrm{RL} \\
\mathrm{mm}\end{array}$ & $\begin{array}{c}\text { DRL } \\
\mathrm{cm} \mathrm{cm}^{-3}\end{array}$ & $\begin{array}{c}\text { RDM } \\
\mathrm{mg}\end{array}$ & $\begin{array}{c}\text { RTD } \\
\mathrm{mg} \mathrm{cm}^{-3}\end{array}$ \\
\hline & & & $\mathrm{LVd}$ & & & \\
\hline $\mathrm{NC}$ & 56.89 & 1.18 & 59.83 & 2.83 & 24.43 & 1.32 \\
\hline $\mathrm{C} 14$ & 49.84 & 1.14 & 54.89 & 2.61 & 22.12 & 1.25 \\
\hline $\mathrm{C} 17$ & 42.57 & 1.07 & 51.76 & 2.47 & 16.59 & 1.04 \\
\hline C110 & 54.56 & 1.09 & 61.48 & 2.89 & 23.13 & 1.27 \\
\hline C310 & 51.59 & 1.16 & 53.65 & 2.55 & 22.72 & 1.26 \\
\hline Mean & 51.09 & 1.13 & 56.32 & 2.67 & 21.80 & 1.23 \\
\hline $\mathrm{F}^{1}$ & $0.68^{\mathrm{ns}}$ & $1.42^{\mathrm{ns}}$ & $0.69^{\text {ns }}$ & $0.72^{\text {ns }}$ & $2.12^{\mathrm{ns}}$ & $1.88^{\mathrm{ns}}$ \\
\hline $\mathrm{CV}(\%)^{1}$ & 38.88 & 10.20 & 26.46 & 24.22 & 28.67 & 18.86 \\
\hline \multicolumn{7}{|l|}{ Layer $(\mathrm{m})$} \\
\hline $0-0.10$ & $70.29 \mathrm{a}$ & 1.16 & $75.03 \mathrm{a}$ & $3.49 \mathrm{a}$ & $26.32 \mathrm{a}$ & $1.40 \mathrm{a}$ \\
\hline $0.10-0.20$ & $49.02 \mathrm{~b}$ & 1.12 & $59.93 \mathrm{~b}$ & $2.56 \mathrm{~b}$ & $21.85 \mathrm{ab}$ & $1.22 \mathrm{~b}$ \\
\hline $0.20-0.30$ & $33.97 \mathrm{c}$ & 1.11 & $40.00 \mathrm{c}$ & $1.96 \mathrm{c}$ & $17.23 \mathrm{~b}$ & $1.07 \mathrm{~b}$ \\
\hline Mean & 51.09 & 1.13 & 58.32 & 2.67 & 21.80 & 1.23 \\
\hline $\mathrm{F}^{2}$ & $27.85^{* *}$ & $1.64^{\mathrm{ns}}$ & $38.19^{* * *}$ & $38.01^{* * *}$ & $10.56^{*}$ & $10.96^{* *}$ \\
\hline$F^{1 \times 2}$ & $0.91^{\mathrm{ns}}$ & $1.19^{\mathrm{ns}}$ & $1.74^{\mathrm{ns}}$ & $1.70^{\mathrm{ns}}$ & $1.48^{\mathrm{ns}}$ & $1.35^{\mathrm{ns}}$ \\
\hline $\mathrm{CV}(\%)^{2}$ & 26.21 & 6.26 & 19.62 & 18.18 & 24.84 & 16.04 \\
\hline & & & LVef & & & \\
\hline $\mathrm{NC}$ & 50.99 & 1.11 & 58.65 & 2.78 & 20.61 & 1.17 \\
\hline $\mathrm{C} 14$ & 58.34 & 1.12 & 65.69 & 3.08 & 23.24 & 1.29 \\
\hline $\mathrm{C} 17$ & 49.05 & 1.07 & 60.15 & 2.83 & 20.09 & 1.16 \\
\hline C110 & 59.01 & 1.10 & 66.68 & 3.12 & 19.90 & 1.16 \\
\hline C310 & 67.24 & 1.16 & 71.52 & 3.34 & 25.16 & 1.35 \\
\hline Mean & 56.93 & 1.11 & 64.54 & 3.03 & 21.71 & 1.23 \\
\hline $\mathrm{F}^{1}$ & $0.95^{\text {ns }}$ & $0.89^{\text {ns }}$ & $0.74^{\mathrm{ns}}$ & $0.73^{\text {ns }}$ & $1.02^{\mathrm{ns}}$ & $1.16^{\mathrm{ns}}$ \\
\hline $\mathrm{CV}(\%)^{1}$ & 39.11 & 8.69 & 28.10 & 26.32 & 31.33 & 19.50 \\
\hline \multicolumn{7}{|l|}{ Layer (m) } \\
\hline $0-0.10$ & $77.08 \mathrm{a}$ & 1.13 & $84.75 \mathrm{a}$ & $3.93 \mathrm{a}$ & 24.70 & $1.34 \mathrm{a}$ \\
\hline $0.10-0.20$ & $54.13 \mathrm{~b}$ & 1.12 & $61.47 \mathrm{~b}$ & $2.89 \mathrm{~b}$ & 20.82 & $1.19 \mathrm{ab}$ \\
\hline $0.20-0.30$ & $39.54 \mathrm{~b}$ & 1.08 & $47.39 \mathrm{c}$ & $2.28 \mathrm{c}$ & 19.88 & $1.14 \mathrm{~b}$ \\
\hline Mean & 56.92 & 1.11 & 64.54 & 3.03 & 21.80 & 1.22 \\
\hline $\mathrm{F}^{2}$ & $17.96^{* * *}$ & $1.34^{\mathrm{ns}}$ & $35.85^{* * *}$ & $35.42^{* * *}$ & $2.91^{\mathrm{ns}}$ & $0.53^{\mathrm{ns}}$ \\
\hline$F^{1 \times 2}$ & $0.88^{\mathrm{ns}}$ & $0.90^{\mathrm{ns}}$ & $1.15^{\mathrm{ns}}$ & $1.13^{\mathrm{ns}}$ & $0.41^{\mathrm{ns}}$ & 19.50 \\
\hline $\mathrm{CV}(\%)^{2}$ & 30.38 & 7.71 & 18.91 & 17.87 & 31.33 & 16.77 \\
\hline
\end{tabular}

NC: without compaction, $\mathrm{C} 14, \mathrm{C} 17$, and C110: one pass of a tractor of 4, 7, and $10 \mathrm{Mg}$, respectively, C310: three passes of a tractor of $10 \mathrm{Mg} .{ }^{(1)} \mathrm{CV}$ (plots) ${ }^{(2)} \mathrm{CV}$ (subplots). Mean followed by the same letter do not differ by the Tukey test $(\mathrm{p}<0.05)$; capital letters refer to the comparison of treatments in the lines; lowercase letters refer to the comparison of layers in the same treatment, in the columns. ns= not significant; ${ }^{*}$ significant $(p<0.05)$ and ${ }^{* *}$ significant $(p<0.01)$.

According to Moraes et al. (2018), the maximum values of PR (1.60 MPa) and Ds $\left(1.67 \mathrm{Mg} \mathrm{m}^{-3}\right)$ of a Rhodic Eutrudox with mean texture under the no-tillage system with the traffic of one, three, and six passes of a tractor of $3.8 \mathrm{Mg}$ did not limit corn's development and root growth. According to these authors, an improvement in soil physical quality occurred, due to the fact of enhancing the water content in the field capacity compared to an area without traffic. It must be taken into consideration that the root growth may be inhibited by PR values inferior to $1 \mathrm{MPa}$ in dry soil. However, with enough humidity, root growth can occur with PR ranging between 4 and 5 MPa (Dexter, 1987).

From the values of root length, it is possible to observe that in $42.88 \%$ and $43.77 \%$ of roots are concentrated in the $0-0.10 \mathrm{~m}$ layer in LVd and LVef, respectively. The results of this study have a lower percentage of corn growth than those showed by Bergamin et al. (2010b). These authors found that the average of treatments considering no-tillage system without and with additional compaction showed $77 \%$ of the CR in the 0-0.10 m layer in a Rhodic Acrustox of clay texture.

In this study, the treatments established by additional compaction induced by tractors were not enough in altering root growth. It would be expected a high concentration of thick roots that encircles the compressed soil layer and with low penetration in this layer (Labegalini et al., 2016).

The NC treatment in the LVd presented higher corn yield (Table 6), even having similar Ds regarding some treatments with compactions induced by tractors. The justification of the values of the Ds is due to the period of sampling being 40 days after sowing. The divergent 
situation in NC may be applied due to the benefit of the soil preparation and by the favorable climate conditions arising from rain during the crop cycle.

It can be noticed that the corn yield decreases as long as the LVef is compacted in the C110 and C310 treatments when compared to the $\mathrm{NC}$ and $\mathrm{C} 14$ (Table $6)$. For the situation in $\mathrm{LVd}$, the different compactions induced by the passes of tractors did not interfere in the corn yield to these classes of soil. When the absolute values are observed, corn yield in LVef was higher than in LVd. This fact is due to the higher content of OM (Table 1) and clay in LVef, which favor the higher adsorption of water.

For the stem diameter, there was no statistical difference between the treatments in both soils. In LVd, the smallest plant height values (Table 6) were verified in C110 and C310 when compared to $\mathrm{NC}, \mathrm{C} 14$, and $\mathrm{C} 17$, and in LVef the smallest plant height value was C310 when compared to the others treatments.
Therefore, there is an indication that the plants received additional compressions (referred to the number of pass and weight of tractors) found limitations to grow when compared to the NC treatments.

It can be noticed in Table 7 that Ds and RA are significant parameters and can be used together PR to evaluate the physical quality in LVd and LVef. This result is also coherent to the ones presented by Lima et al. (2014), in which Ds was the physical attribute in Yellow Oxisol that showed the highest positive correlation with PR. In this aspect, for Benedetti et al. (2010), PR was highly influenced by Ds in different systems of use of the soil. The present study highlights the influence of the soil compaction on the morphological alterations of corn plants. Therefore, the choice of complementary parameters to PR to compose a group of indicators of soil is recommended to consider the characteristics such as mineralogy, texture, parameters of the aerial and root part of the cultures.

Table 6. Yield, plant height and diameter of corn in Haplustox (LVd) and Eutrustox (LVef), under different traffic intensities.

\begin{tabular}{|c|c|c|c|c|c|c|}
\hline Treatments & Yield & Height & Diameter & Yield & Height & Diameter \\
\hline & $\mathrm{t} \mathrm{ha}^{-1}$ & $\mathrm{~m}$ & $\mathrm{~mm}$ & $\mathrm{t} \mathrm{ha}^{-1}$ & $\mathrm{~m}$ & $\mathrm{~mm}$ \\
\hline $\mathrm{NC}$ & $9.23 \mathrm{a}$ & $\begin{array}{l}--L V d- \\
2.08 \mathrm{a}\end{array}$ & 16.15 & $7.32 \mathrm{a}$ & $\begin{array}{l}--L V e f- \\
2.10 \mathrm{a}\end{array}$ & 15.66 \\
\hline $\mathrm{C} 14$ & $7.57 \mathrm{~b}$ & $2.05 \mathrm{a}$ & 16.49 & $7.50 \mathrm{a}$ & $2.00 \mathrm{ab}$ & 17.16 \\
\hline $\mathrm{C} 17$ & $7.93 \mathrm{~b}$ & $1.99 \mathrm{a}$ & 17.13 & $6.69 \mathrm{ab}$ & $1.88 \mathrm{bc}$ & 16.09 \\
\hline $\mathrm{C} 110$ & $6.76 \mathrm{~b}$ & $1.76 \mathrm{~b}$ & 17.36 & $5.62 \mathrm{~b}$ & $1.71 \mathrm{c}$ & 18.81 \\
\hline C310 & $7.28 \mathrm{~b}$ & $1.79 \mathrm{~b}$ & 17.34 & $5.17 \mathrm{~b}$ & $1.34 \mathrm{~d}$ & 17.48 \\
\hline F & $11.18^{* *}$ & $21.00^{* *}$ & $0.53^{\mathrm{ns}}$ & $8.29^{* *}$ & $51.67^{* *}$ & $1.74^{\mathrm{ns}}$ \\
\hline $\mathrm{CV}(\%)$ & 17.17 & 13.38 & 18.87 & 11.05 & 14.59 & 11.03 \\
\hline
\end{tabular}

NC: without compaction, C14, C17, and C110: one pass of a tractor of 4, 7, and $10 \mathrm{Mg}$, respectively, C310: three passes of a tractor of $10 \mathrm{Mg}$. Means followed by the same letter do not differ by the Tukey test $(\mathrm{p}<0.05)$; ns = not significant and ${ }^{* *}$ significant $(\mathrm{p}<$ $0.01)$.

Table 7. Summary of the multiple regression analysis of the dependable variable: PR in Haplustox (LVd) and Eutrustox (LVef), under different intensities of traffic $(\mathrm{N}=40)$.

\begin{tabular}{ccccccc}
\hline & $\beta$ & Standard error of $\beta$ & $\mathrm{B}$ & Standard error of $\beta$ & $\mathrm{t}(25)$ & $\mathrm{p}$ level \\
\hline Intercept & & & -0.030 & 0.873 & -0.035 & $0.972^{\mathrm{ns}}$ \\
MGD & 0.353 & 0.650 & 0.353 & 0.650 & 0.543 & $0.592^{\mathrm{ns}}$ \\
MWD & -0.244 & 0.691 & -0.244 & 0.691 & $-0,353$ & $0.727^{\mathrm{ns}}$ \\
Soil Density & 0.541 & 0.197 & 0.541 & 0.197 & 2.746 & $0.011^{*}$ \\
Macroporosity & -0.150 & 0.160 & -0.150 & 0,160 & -0.937 & $0.358^{\mathrm{ns}}$ \\
Microporosity & 0.254 & 0.201 & 0.254 & 0.201 & 1.266 & $0.217^{\mathrm{ns}}$ \\
Corn Height & -0.369 & 0.185 & -0.369 & 0.185 & -1.995 & $0.057^{\mathrm{ns}}$ \\
Corn Diameter & 0.128 & 0.100 & 0.128 & 0.100 & 1.279 & $0.213^{\mathrm{ns}}$ \\
Corn Yield & -0.149 & 0.151 & -0.149 & 0.151 & -0.991 & $0.331^{\mathrm{ns}}$ \\
RA & -0.386 & 0.173 & -0.386 & 0.173 & -2.231 & $0.035^{*}$ \\
RD & 0.043 & 0.169 & 0.043 & 0.169 & 0.252 & $0.803^{\mathrm{ns}}$ \\
RL & 0.342 & 0.216 & 0.342 & 0,216 & 1.584 & $0.126^{\mathrm{ns}}$ \\
DRL & -0.050 & 0.147 & -0.050 & 0.147 & -0.339 & $0.738^{\text {ns }}$ \\
RDM & -0.050 & 0.292 & -0.050 & 0.292 & -0.172 & $0.865^{\mathrm{ns}}$ \\
RTD & 0.010 & 0.278 & 0.029 & 0.835 & 0.035 & $0.972^{\mathrm{ns}}$ \\
\hline
\end{tabular}

$\mathrm{r}=0.927 ; \mathrm{R}^{2}=0.860 ;$ Adjusted $\mathrm{R}^{2}=0.782 ; \mathrm{F}(14.25)=10.98 ; \mathrm{p}<0.000 ;$ estimated standard error $=0.467 . \mathrm{ns}=$ not significant and ${ }^{*}$ significant $(\mathrm{p}<0.05)$. 


\section{Conclusions}

The soil bulk density and root area of the corn are the parameters indicated to evaluate the soil quality together with the soil penetration resistance.

The compactions induced by tractors are harmful to the aggregation, as well as the conventional preparation in LVd and LVef.

The treatments established by additional compression by tractors were not enough to alter the root growth.

\section{Acknowledgments}

To the Coordenação de Aperfeiçoamento de Pessoal de Nível Superior (CAPES), for the concession of the scholarship to the first author.

\section{Bibliographic References}

Balin, N.M., Ziech, A.R.D., Oliveira, J.P.M.O., Girardello, V.C., Stumpf, L., Conceição, P.C., 2017. Frações da matéria orgânica, índice de manejo do carbono e atributos físicos de um Latossolo Vermelho sob diferentes sistemas de uso. Scientia Agraria, 18(3), 85-94. DOI: http://dx.doi.org/10.5380/rsa.v18i3.53114.

Barbosa, L.C., Zigomar, M.S., Franco, H.C.J., Otto, R., Rossi Neto, J., Garside, A.L., Carvalho, J.L.N., 2018. Soil texture affects root penetration in Oxisols under sugarcane in Brazil. Geoderma Regional, 13(6), 15-25. DOI: https://doi.org/10.1016/j.geodrs.2018.03.002.

Benedetti, M.M., Duarte, I.N., Melo Junior, H.B., Borges, E.N., 2010. Resistência do solo à penetração em um Latossolo Vermelho distrófico típico sob diferentes usos. Enciclopédia Biosfera, 6(11), 1-9.

Bengough, A.G., Mckenzie, B.M., Hallett, P.D., Valentine, T.A., 2011. Root elongation, water stress, and mechanical impedance: a review of limiting stresses and beneficial root tip traits. Journal of Experimental Botany, 62(1), 59-68. DOI: https://doi.org/10.1093/jxb/erq350.

Bergamin, A.C., Vitorino, A.C.T., Franchini, J.C., Souza, C.M.A., Souza, F.R., 2010a. Compactação de um Latossolo Vermelho distroférrico e suas relações com o crescimento radicular do milho. Revista Brasileira de Ciência do Solo, 34(3), 681-691. DOI: https://doi.org/10.1590/S010006832010000300009.

Bergamin, A.C., Vitorino, A.C.T., Lempp, B., Souza, C.M.A., Souza, F.R, 2010b. Anatomia radicular de milho em solo compactado. Pesquisa Agropecuária Brasileira, 45(3), 299$305 . \quad$ DOI: $\quad$ https://doi.org/10.1590/S0100204X2010000300010.

Dexter, A.R., 1987. Mechanics of root growth. Plant and Soil, 98(1), 303-312.

EMBRAPA. Empresa Brasileira de Pesquisa Agropecuária, 2017. Manual de métodos de análises de solo, terceira ed. rev. Rio de Janeiro, Embrapa Solos, 230 p.
EMBRAPA. Empresa Brasileira de Pesquisa Agropecuária, 2018. Sistema brasileiro de classificação de solos, quinta ed. rev. e ampl. Brasília, Embrapa Solos, 586 p.

FAO. Food and Agriculture Organization of the United Nations, 2015. Status of the world's soil resources. Rome, Intergovernmental Technical Panel on Soils, 648 p.

Freddi, O.S., Centurion, J.F., Beutler, A.N., Aratani, R.G., Leonel, C.L., 2007. Compactação do solo e no crescimento radicular e produtividade da cultura do milho. Revista Brasileira de Ciência do Solo, 31(4), 627-636. DOI: https://doi.org/10.1590/S0100-06832007000400003.

Freddi, O.S., Centurion, J.F., Duarte, A.P., Peres, F.S.C., 2009. Compactação do solo e produção de cultivares de milho em Latossolo Vermelho. II - Intervalo hídrico ótimo e sistema radicular. Revista Brasileira de Ciência do Solo, 33(4), 805818. DOI: https://doi.org/10.1590/S010006832009000400006

Freitas, E.C.S., Oliveira Neto, S.N., Fonseca, D.M., Santos, M.V., Leite, H.G., Machado, V.D., 2010. Deposição de serapilheira e de nutrientes no solo em sistema agrossilvipastoril com eucalipto e acácia. Revista Árvore, 37(3), 409-417. DOI: https://doi.org/10.1590/S010067622013000300004

Imhoff, S., Silva, A.P., Ghiberto, P.J. Tormena, C.A., Pilatti, M.A., Libardi, P.L., 2016. Physical quality indicators and mechanical behavior of agricultural soils of Argentina. Plos One, 11(4), e0153827. DOI: https://doi.org/10.1371/journal.pone.0153827.

Keller, T., Lamandé, M., Peth, S., Berli, M., Delenne, J.Y., Baumgarten, W., Rabbel, W., Radjai, F., Rajchenbach, J., Selvadurai, A.P.S., Or, D., 2013. An interdisciplinary approach towards improved understanding of soil deformation during compaction. Soil and Tillage Research, 128(4), 61-80. DOI: https://doi.org/10.1016/j.still.2012.10.004.

Kemper, W.D., Chepil, W.S., 1965. Size distributions of aggregates, in: Black, C.A., (Ed.), Methods of soil analysis. Madison, American Society of Agronomy, p. 449-510.

Labegalini, N.S., Buchelt, A.C., Andrade, L., Oliveira, S.C., Campos, L.M., 2016. Desenvolvimento da cultura do milho sob efeitos de diferentes profundidades de compactação do solo. Revista de Agricultura Neotropical, 3(4), 7-11. DOI: https://doi.org/10.32404/rean.v3i4.1102.

Lima, R.P., Silva, A.R., Oliveira, D.M.S., 2014. Análise de trilha de atributos físicos na resistência à penetração de um Latossolo Amarelo. Revista de Agricultura Neotropical, 1(1), 65-74. DOI: https://doi.org/10.32404/rean.v1i1.216.

Moraes, M.T., Debiasi, H., Carlesso, R., Franchini, J.C., Silva, V.R., 2014. Critical limits of soil penetrations resistance in a Rhodic Eutrudox. Revista Brasileira de Ciência do Solo, 38(1), 288-298. DOI: https://doi.org/10.1590/S010006832014000100029

Moraes, M.T., Levien, R., Trein, C.R., Bonetti, J.A, Debiasi, H., 2018. Corn crop performance in an Ultisol compacted by tractor traffic. Pesquisa Agropecuária Brasileira, 53(4), 464$477 . \quad$ DOI: $\quad$ https://doi.org/10.1590/s0100$204 \times 2018000400008$ 
Nascente, A.S., Yuncong, L., Crusciol, C.A.C., 2015. Soil aggregation, organic carbon concentration, and soil bulk density as affected by cover crop species in a no-tillage system. Revista Brasileira de Ciência do Solo, 39(3), 871-879. DOI: https://doi.org/10.1590/01000683rbcs20140388.

Nunes, M.R., Denardin, J.E., Pauletto, E.A., Faganello, A., Pinto, L.F.S., 2015. Effect of soil chiseling on soil structure and root growth for clayey soil under no-tillage. Geoderma, 259-260(12), 149-155.

DOI:

https://doi.org/10.1016/j.geoderma.2015.06.003.

Oliveira, P.R., Centurion, J.F., Centurion, M.A.P.C., Franco, H.B.J., Pereira, F.S., Bárbaro Júnior, L.S., Rossetti, K.V., 2012. Qualidade física de um Latossolo Vermelho cultivado com soja submetido a níveis de compactação e de irrigação. Revista Brasileira de Ciência do Solo, 36(2), 587-597. DOI: https://doi.org/10.1590/S0100-06832012000200028.

Otto, R., Silva, A.P., Franco, H.C.J., Oliveira, E.C.A., Trivelin, P.C.O., 2011. High soil penetration resistance reduces sugarcane root system development. Soil and Tillage Research, 117(12), 201-210. DOI: https://doi.org/10.1016/j.still.2011.10.005.

Raij, B. van., Andrade, J.C., Cantarella, H., Quaggio, J.A., 2001. Análise química para avaliação da fertilidade de solos tropicais. Campinas, Instituto Agronômico.

Reichert, J.M., Suzuki, L.E.A.S., Reinert, J., Horn, R., Hakansson, I., 2009. Reference bulk density and critical degree-of-compactness for no-till crop production in subtropical highly weathered soils. Soil and Tillage Research, 102(2), 242-254. DOI: https://doi.org/10.1016/j.still.2008.07.002.

Resende, M., Curi, N., Poggere, G.C., Barbosa, J.Z., Pozza, A.A.A., 2019. Pedologia, fertilidade, água e planta: Interrelaçãoes e aplicações. Lavras, UFLA.
Rossetti, K.V., Centurion, J.F., Sousa Neto, E.L., 2013. Physical quality of an Oxisol after different periods of management systems. Revista Brasileira de Ciência do Solo, 37(6), 1522-1534. DOI: https://doi.org/10.1590/S010006832013000600009 .

Silva, E.A.A., Uribe-Opazo, M.A., Rocha, J.V., Souza, E.G., 2003. Um estimador robusto e o semivariograma cruzado na análise de variabilidade especial de atributos do solo e planta. Acta Scientiarum, 25(2), 365-371. DOI: https://doi.org/10.4025/actasciagron.v25i2.1984.

Teixeira, G.C.S., Reis, E.F., Teixeira, I.R., Freitas, R.J., Santos, F.L.S., 2017. Physical properties of soils under different management systems in the Cerrado region of Brazil. Australian Journal of Crop Science, 11(11), 1418-1424. DOI: https://10.21475/ajcs.17.11.11.pne541.

Tormena, C.A., Silva, A.P., Libardi, P.L., 1998. Caracterização do intervalo hídrico ótimo de um Latossolo Roxo sob plantio direto. Revista Brasileira de Ciência do Solo, 22(4), 573-581. DOI: https://doi.org/10.1590/S010006831998000400002 .

Valentine, T.A., Hallett, P.D., Binnie, K., Young, M.W., Squire, G.R., Hawes, C., Bengough, A.G., 2012. Soil strength and macropore volume limit root elongation rates in many UK agricultural soils. Annals of Botany, 110(7), 259-270. DOI: https://doi.org/10.1093/aob/mcs118.

Yoder, R.E.A., 1936. Direct method of aggregate analysis of soils and a study of the physical nature of erosion losses. Journal American Society Agronomy, 28(5), 337-351. DOI: https://doi.org/10.2134/agronj1936.00021962002800050001x. 